University of Nebraska - Lincoln

DigitalCommons@University of Nebraska - Lincoln

USDA National Wildlife Research Center - Staff Publications
U.S. Department of Agriculture: Animal and Plant Health Inspection Service

January 2001

\title{
Avian Use of Various Bait Mixtures Offered in Harvested Cornfields during Spring Migration in South Dakota
}

\author{
George M. Linz \\ H. Jeffrey Homan \\ National Wildlife Research Center, U.S. Department of Agriculture \\ Ryan L. Wimberly \\ National Wildlife Research Center, U.S. Department of Agriculture
}

USDA/APHIS/WS National Wildlife Research Center, george.m.linz@aphis.usda.gov

Follow this and additional works at: https://digitalcommons.unl.edu/icwdm_usdanwrc

Part of the Environmental Sciences Commons

\footnotetext{
Linz, George M.; Homan, H. Jeffrey; and Wimberly, Ryan L., "Avian Use of Various Bait Mixtures Offered in Harvested Cornfields during Spring Migration in South Dakota" (2001). USDA National Wildlife Research Center - Staff Publications. 591.

https://digitalcommons.unl.edu/icwdm_usdanwrc/591
}

This Article is brought to you for free and open access by the U.S. Department of Agriculture: Animal and Plant Health Inspection Service at DigitalCommons@University of Nebraska - Lincoln. It has been accepted for inclusion in USDA National Wildlife Research Center - Staff Publications by an authorized administrator of DigitalCommons@University of Nebraska - Lincoln. 
Published in Pesticides and Wildlife, edited by John J. Johnston. ACS Symposium Series 771. American Chemical Society, Washington, DC, 2001. 


\title{
Chapter 24
}

\section{Avian Use of Various Bait Mixtures Offered in Harvested Cornfields during Spring Migration in South Dakota}

\author{
George M. Linz, H. Jeffrey Homan, and Ryan L. Wimberly \\ National Wildlife Research Center, U.S. Department of Agriculture, 2110 \\ Miriam Circle, Bismark, ND 58501
}

The avicide, DRC-1339, is used to cull populations of springmigrating blackbirds in eastern South Dakota to reduce damage to ripening sunflower in late summer. We investigated nontarget bird hazards associated with using various grain mixtures to attract blackbirds (Icteridae), especially red-winged blackbirds (Agelaius phoeniceus), to avicide-treated bait broadcast in harvested cornfields. During spring 1997 and 1998, we recorded the species and numbers of birds attracted to 0.2 -ha plots baited with cracked corn and brown rice, fine-chipped sunflower meats and brown rice (1997 only), and unsupplemented brown rice. Unbaited plots were used as reference sites. In 1997 and 1998, nontarget birds showed no preference among bait mixtures $(P$ 's $>0.16)$. In 1997, blackbird preference did not differ among bait mixtures $(P>0.12)$; whereas, in 1998, blackbirds preferred the corn/rice mixture over rice $(P=0.02)$. Our data show that augmenting brown rice with cracked corn or sunflower meats poses little additional risk to nontarget birds and may help attract blackbirds to the baitsite.

In the northern Great Plains, millions of blackbirds (Icteridae) begin feeding on maturing sunflower in mid-August (I), causing annual losses of $5-\$ 10$ million before the crop is harvested in October $(2,3)$. Sunflower producers began calling for the reduction of blackbird populations in the northern Great Plains shortly after the crop became economically viable in the early 1970s (4). DRC-1339 (3-Chloro- $p$-toluidine), an avicide developed by the U.S. Fish and Wildlife Service for controlling European starlings (see tables for scientific names) at feedlots (5), was touted as an environmentally safe avicide for reducing spring-migrating blackbird populations responsible for damaging sunflower (4). Designated by the U. S. 
Environmental Protection Agency (EPA) as a restricted-use pesticide, DRC-1339 can only be applied by trained personnel in the U.S. Department of Agriculture, Animal Plant Health Inspection Service, Wildlife Services program.

In March 1993, we initiated a long-term study to evaluate the use of DRC-1339-treated rice for culling spring-migrating blackbird populations congregating in eastern South Dakota (6). The management goal is to cull the breeding population thereby reducing late-summer populations of blackbirds responsible for damaging sunflower (7). The treated baits are spread in harvested grain fields raising concerns among wildlife agencies about acute and chronic poisoning of nontarget species (8). Currently, DRC-1339 is applied to brown rice and broadcast in harvested cornfields within $50 \mathrm{~m}$ of a road (9). Although blackbirds eat rice in the southern United States, rice may not be a favored food of springmigrating blackbirds in South Dakota, and by providing an additional food item along with the treated rice may entice more blackbirds to feed in our baited plots.

Field data comparing preferences of blackbirds and nontarget birds for various bait combinations are not available. Our objective was to assess the preferences of blackbirds and nontarget birds for different bait mixtures.

\section{Study Area and Methods}

\section{Study Area}

Our study was conducted in Brookings, Miner, and Lake counties in east-central South Dakota. This region of low, rolling hills has been developed for agriculture but still has an abundance of undrained lakes and potholes. Of about 370,000 ha of cropland in these counties, $46 \%$ was soybean, $43 \%$ corn, and $8 \%$ wheat (10). The remaining 156,100 ha of land consisted of hayland (39\%), Conservation Reserve Program lands (14\%), and wetlands (47\%). The long-term average temperature and precipitation during our March-April study period were $2.2^{\circ} \mathrm{C}$ and $4.2 \mathrm{~cm}$, respectively. In 1997 , temperatures averaged $0^{\circ} \mathrm{C}$ and precipitation totaled $4.1 \mathrm{~cm}$; while in 1998 , the average temperature was $2.2^{\circ} \mathrm{C}$ and precipitation totaled $2.9 \mathrm{~cm}$ (10).

\section{Baiting Procedure}

In 1997, we placed a pair of 0.8-ha (2-acre) plots in each of three harvested corn fields in attractive locations for blackbirds and nontarget birds (e.g., near woodlots and grasslands). The nearest edge of each plot was about $25 \mathrm{~m}$ from the road. Each 0.8-ha plot was subdivided into four 0.2 ha ( 0.5 acre) subplots and randomly assigned one of the following treatments: $2.8 \mathrm{~kg}$ rice $(6.25 \mathrm{lb})$ and $2.8 \mathrm{~kg}$ fine-chipped sunflower meats, $2.8 \mathrm{~kg}$ brown rice and $2.8 \mathrm{~kg}$ cracked corn, $2.8 \mathrm{~kg}$ rice, and no bait. An all-terrain vehicle, equipped with a seed spreader, was used to apply baits. An unbaited buffer zone of about 3-m was left between subplots.
In 1998, we used a similar design except the rice/sunflower treatment was canceled and sample size was increased to four harvested fields. Plots were subdivided into three $33 \times 33 \mathrm{~m}(0.2 \mathrm{ha})$ subplots with about a 3-m buffer between them. Each 0.2-ha subplot randomly received either $11.3 \mathrm{~kg}$ brown rice and $11.3 \mathrm{~kg}$ cracked corn, 11.3 $\mathrm{kg}$ rice, or no bait.

In both years, we established four bait stations $(30.5 \times 30.5 \mathrm{~cm})$ in the reference and baited subplots to monitor bait consumption. The stations contained 10 rice kernels and were checked at least every three days, weather permitting. Subplots were rebaited after $75 \%$ of the bait at the stations was eaten or when precipitation exceeded $10 \mathrm{~mm}$ ( 0.4 inches).

\section{Food Characteristics}

Percent analyses of dry matter, ash, crude protein, acid detergent fiber, and gross energy $(\mathrm{kcal} / \mathrm{g})$ of each food were reported previously (11). Briefly, percent dry matter was essentially equal among the three foods, averaging $92 \%$. Sunflower contained $29 \%$ crude protein whereas, rice and corn had about $10 \%$ protein. Brown rice had $4 \%$ ash and $2 \%$ fiber, which was three times more ash and three times less fiber than corn and sunflower. Finally, sunflower contained $7.3 \mathrm{kcal} / \mathrm{g}$; whereas, cracked corn and brown rice contained about $4.5 \mathrm{kcal} / \mathrm{g}$.

\section{Plot Observations}

Between 1 April and 25 April 1997, we observed each plot at least every third day beginning at sunrise to three hours after sunrise and from three hours before sunset to sunset. The observer arrived about $1 / 2 \mathrm{hr}$ before the start of each one hour observation period and erected a blind on a 3-m high platform affixed to a truck (5). The nearest edge of each plot was about $25 \mathrm{~m}$ from the truck. After waiting $15 \mathrm{~min}$, the observer began recording all birds that landed in the first randomly selected subplot for $30 \mathrm{sec}$ The observer then paused $30 \mathrm{sec}$ before recording data in the next plot. After all four subplots had been censused, the observer rested for one minute and repeated the procedure.

In 1998, plots were observed from 27 March to 22 April. Procedures for observing plots were altered so that each 0.2 -ha subplot was observed for one minute with a one minute data-recording period between observation periods. Observations were not conducted during steady precipitation or if the wind exceeded $32 \mathrm{~km} / \mathrm{hr}$ because of poor visibility.

\section{Statistical Analyses}

Target birds, as defined under the FIFRA (Federal Insecticide Fungicide and Rodenticide Act) Section 3 Label 'Compound DRC-1339 Concentrate-Staging Areas' 
(EPA registration number 56228-30), included red-winged blackbirds, yellow-headed blackbirds, common grackles, Brewer's blackbirds, European starlings, and brown-headed cowbirds (12). All other birds were considered nontargets.

We used Kruskal-Wallis tests to examine the null hypothesis that the number of blackbirds and nontarget birds recorded per hour were similar among the bait treatments and the reference plots and the three bait treatments (13). For the 1998 data, we used the Wilcoxon 2-sample test because we only had two bait treatments (13).

The significance level was set at 0.05 for all statistical tests. Means and standard errors are reported as $\bar{x} \pm S E$. To illustrate the temporal dynamics of bird migration, we graphed 7-day moving averages of the mean numbers of birds/hour in the plots.

\section{Results}

1997

Blackbirds were observed in greater numbers in baited subplots than unbaited reference subplots $\left(\chi^{2}<9.63, \mathrm{df}=3, P>0.02\right)$; however, we detected no difference in the number of birds using the three bait mixtures $\left(\chi^{2}=4.22, \mathrm{df}=2, P=0.12\right)$. In comparison, nontarget use of baited and unbaited subplots was similar $\left(\chi^{2}=1.96, \mathrm{df}\right.$ $=3, P=0.58$ ). During 86 hours of observations, numbers of blackbirds averaged $84.0( \pm 16.6)$ and nontarget birds $1.5( \pm 0.3)$. Blackbird migration peaked during mid-April (Figure 1), one week later than the peak for nontargets (Figure 1).

\section{8}

More blackbirds $\left(\chi^{2}=21.8, \mathrm{df}=2, P<0.01\right)$ and nontarget birds $\left(\chi^{2}=8.64, \mathrm{df}=\right.$ $2, P=0.01)$ were recorded using subplots baited with corn/rice or unsupplemented rice than unbaited plots. We counted more blackbirds in subplots baited with corn/rice than brown rice $(Z=2.26, \mathrm{df}=1, P=0.02)$. However, abundance of nontargets did not differ between these two baits $(Z=1.40, \mathrm{df}=1, P=0.16)$. During 66 hours of observation, mean numbers of blackbirds and nontargets observed per hour in all subplots were $29.4 \pm 8.1$ and $3.2 \pm 0.6$, respectively. Migration peaks for blackbirds and nontarget birds were similar, occurring in early April. (Figure 1).

\section{Years Combined}

We observed 21 nontarget birds species during 152 hours of observations. After pooling the data across years, we found that the numbers of blackbirds differed $\left(\chi^{2}=\right.$ $6.49, \mathrm{df}=2, P=0.04$ ) among the baited subplots (Table I), with the blackbirds preferring sunflower/rice over corn/rice and rice alone. In comparison, over-al
BLACKBIRDS

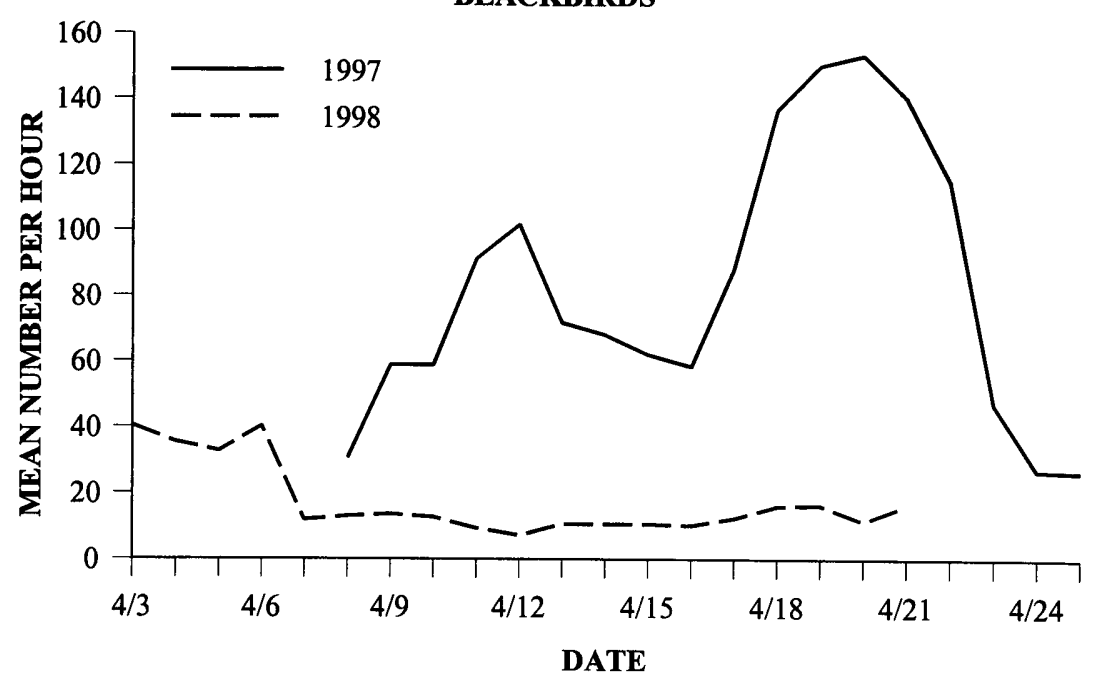

NONTARGET BIRDS

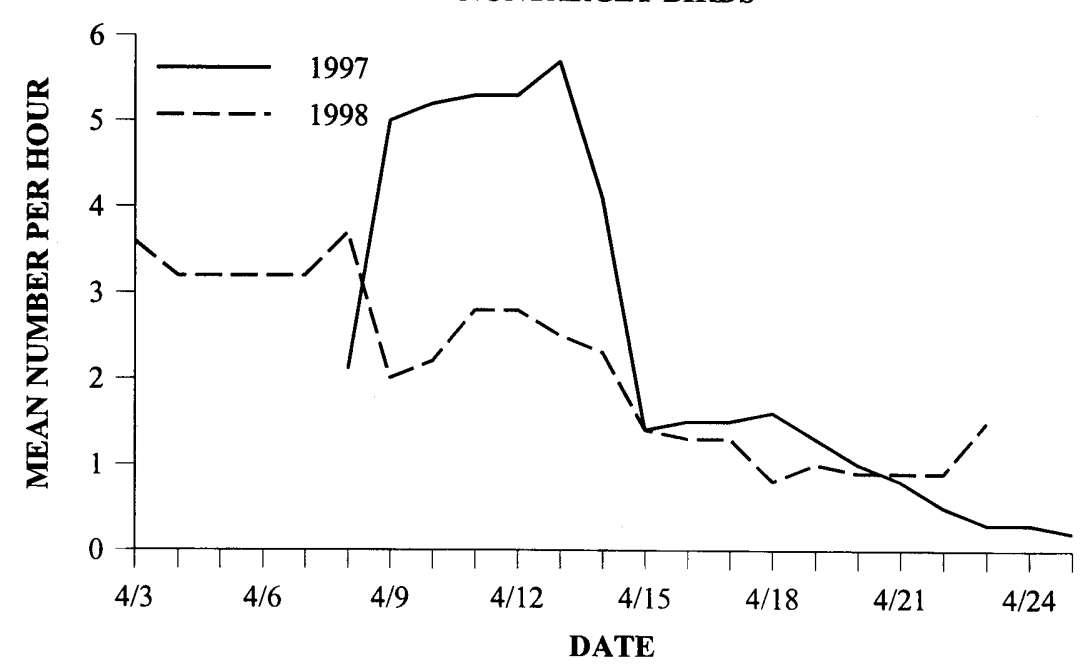

Figure 1. Seven-day moving average of the mean number of blackbirds and nontarget birds using 6-0.2 ha subplots in harvested cornfields in east-central South Dakota during April 1997 and 1998. 
numbers of nontarget birds recorded were similar among bait mixtures $\left(\chi^{2}=2.13\right.$, df $=2, P=0.34)($ Table II)

\section{Discussion}

Table I. Target birds observed in east-central South Dakota cornfields containing 0.2 ha areas of bait mixture combinations of fine-chipped sunflower and brown rice, cracked corn and brown rice, and brown rice during March and April 1997 and 1998.

\section{Bait Type}

Sunflower $^{a}$ Corn $^{b} \quad$ Rice $^{b} \quad$ Reference $^{b}$ Mean Number Per Hour

Common Name Scientific Name $\quad$ (Percent Frequency of Occurrence)

\begin{tabular}{llllll}
\hline $\begin{array}{l}\text { European } \\
\text { starling }\end{array}$ & Sturnus vulgaris & $0.00(0)$ & $0.09(2)$ & $0.01(<1)$ & $0.00(0)$ \\
$\begin{array}{l}\text { Yellow-headed } \\
\text { blackbird }\end{array}$ & $\begin{array}{l}\text { Xanthocephalus } \\
\text { xanthocephalus }\end{array}$ & $4.58(31)$ & $4.35(24)$ & $3.01(16)$ & $1.64(15)$ \\
$\begin{array}{l}\text { Brewer's } \\
\text { blackbird }\end{array}$ & $\begin{array}{l}\text { Euphagus } \\
\text { cyanocephalus }\end{array}$ & $0.80(5)$ & $0.20(1)$ & $0.05(1)$ & $0.20(<1)$ \\
$\begin{array}{l}\text { Brown-headed } \\
\text { cowbird }\end{array}$ & Molothrus ater & $0.15(8)$ & $0.31(11)$ & $0.13(8)$ & $0.03(1)$ \\
$\begin{array}{l}\text { Red-winged } \\
\text { blackbird }\end{array}$ & $\begin{array}{l}\text { Agelaius } \\
\text { phoeniceus }\end{array}$ & $70.01(64)$ & $48.65(53)$ & $42.65(47)$ & $27.06(35)$ \\
$\begin{array}{l}\text { Common } \\
\text { grackle }\end{array}$ & $\begin{array}{l}\text { Quiscalus } \\
\text { quiscula }\end{array}$ & $22.15(24)$ & $13.66(20)$ & $13.95(14)$ & $17.06(10)$ \\
Mean & & $97.8(65)$ & $67.3(55)$ & $59.8(49)$ & $46.0(36)$ \\
\hline
\end{tabular}

${ }^{a} n=86$ observation hours

${ }^{b} n=152$ observation hours

\section{Bait Selection}

In both years, blackbirds consistently selected against unbaited subplots and tended to select the highest energy food mixture available, suggesting that blackbirds choose feeding sites based on food quantity and probably food quality. An assessment of food preference is confounded by several factors, including food characteristics such as color, size, taste, and caloric content $(13,14,15)$, and the morphology of the bird. For example, in a cage study, female red-winged blackbirds, which are $30 \%$ smaller than males, clearly chose brown rice over cracked-corn (1I). On the other hand, males showed no consistent food preference. It probably was easier for the smallerbilled females to handle rice than cracked corn.

\section{Migration and feeding ecology}

In 1997 and 1998, we observed 21 nontarget bird species in our study plots. In comparison, Kenyon (16) recorded 12 species in 1995, and Knutsen (9) detected 13 species in 1996 and 1997 (Table III). Across all four years, 24 nontarget species were recorded in cornfields in east-central South Dakota. We believe that nearly all nontarget birds that commonly use harvested corn in east-central South Dakota from mid-March to late April were recorded during these three studies.

In 1997, Lapland longspurs, which normally migrate north from east-central South Dakota by mid- to late March, were abundant in the study area until mid-April because of harsh weather. In comparison, large numbers of blackbirds and other early migrant species such as western meadowlarks, mallards, snow geese, and American robins were not observed in appreciable numbers in South Dakota until late March 1997. Differences in migrational timing between study years were probably related to the mild, late-winter weather that created open agricultural land two weeks earlier in 1998 than in 1997, allowing for an earlier arrival of migrant birds $(17,18)$.

From 1995 to 1998, six members of the sparrow family (Emberizidae) were observed in our study plots; none, however, have been tested for susceptibility to DRC-1339. We recommend $L D_{50 s}$ for some or all of these birds because their granivorous food habits, small size, and flock feeding behavior may make them vulnerable to DRC-1339 poisoning.

Other birds frequently observed in the plots included American robins, killdeers, and American coots. The foraging habits and diets of these species make it unlikely that they will be adversely affected by DRC-1339-treated rice baits $(8,19)$. On the other hand, western meadowlarks, as members of the highly vulnerable blackbird 
Table II. Nontarget birds observed in east-central South Dakota cornfields containing 0.2 ha areas of bait mixture combinations of fine-chipped sunflower and brown rice, cracked corn and brown rice, and brown rice during March and April 1997 and 1998.

\begin{tabular}{|c|c|c|c|c|c|}
\hline \multirow{3}{*}{$\begin{array}{l}\text { Common Name } \\
\text { Canada goose }\end{array}$} & \multirow{3}{*}{$\begin{array}{l}\text { Scientific Name } \\
\begin{array}{l}\text { Branta } \\
\text { canadensis }\end{array}\end{array}$} & \multicolumn{4}{|c|}{ Bait Type } \\
\hline & & \multicolumn{4}{|c|}{$\begin{array}{c}\text { Mean Number Per Hour } \\
\text { (Percent Frequency of Occurrence) }\end{array}$} \\
\hline & & $0.01(1)$ & $0.00(0)$ & $0.00(0)$ & $0.00(0)$ \\
\hline Wood duck & Aix sponsa & $0.12(1)$ & $0.06(1)$ & $0.00(0)$ & $0.00(0)$ \\
\hline Northern pintail & Anas acuta & $0.00(0)$ & $0.01(<1)$ & $0.00(0)$ & $0.00(0)$ \\
\hline Blue-winged teal & Anas discors & $0.00(0)$ & $0.01(<1)$ & $0.00(0)$ & $0.00(0)$ \\
\hline $\begin{array}{l}\text { Northern } \\
\text { shoveler }\end{array}$ & Anas clypeata & $0.06(1)$ & $0.00(0)$ & $0.00(0)$ & $0.00(0)$ \\
\hline $\begin{array}{l}\text { Ring-necked } \\
\text { pheasant }\end{array}$ & $\begin{array}{l}\text { Phasianus } \\
\text { colchicus }\end{array}$ & $0.00(0)$ & $0.01(<1)$ & $0.00(0)$ & $0.03(1)$ \\
\hline Killdeer & $\begin{array}{l}\text { Charadrius } \\
\text { vociferus }\end{array}$ & $0.04(4)$ & $0.07(5)$ & $0.11(6)$ & $0.11(5)$ \\
\hline Common snipe & $\begin{array}{l}\text { Gallinago } \\
\text { gallinago }\end{array}$ & $0.00(0)$ & $0.03(<1)$ & $0.01(1)$ & $0.01(1)$ \\
\hline Mourning dove & $\begin{array}{l}\text { Zenaida } \\
\text { macroura }\end{array}$ & $0.02(1)$ & $0.09(4)$ & $0.10(3)$ & $0.01(<1)$ \\
\hline $\begin{array}{l}\text { Downy } \\
\text { woodpecker }\end{array}$ & $\begin{array}{l}\text { Picoides } \\
\text { pubescens }\end{array}$ & $0.00(0)$ & $0.01(1)$ & $0.01(<1)$ & $0.01(<1)$ \\
\hline Northern flicker & Colaptes auratus & $0.01(1)$ & $0.20(<1)$ & $0.02(1)$ & $0.01(<1)$ \\
\hline Horned lark & $\begin{array}{l}\text { Eremophila } \\
\text { alpestris }\end{array}$ & $0.05(1)$ & $0.16(4)$ & $0.12(4)$ & $0.05(2)$ \\
\hline American robin & $\begin{array}{l}\text { Turdus } \\
\text { migratorius }\end{array}$ & $0.00(0)$ & $0.07(2)$ & $0.10(4)$ & $0.17(4)$ \\
\hline Water pipit & Anthus spinoletta & $0.00(0)$ & $0.00(0)$ & $0.03(2)$ & $0.00(0)$ \\
\hline
\end{tabular}

Table II. Continued

\begin{tabular}{|c|c|c|c|c|c|}
\hline \multirow{3}{*}{$\begin{array}{l}\text { Common Name } \\
\text { American tree } \\
\text { sparrow }\end{array}$} & \multirow{3}{*}{$\begin{array}{l}\text { Scientific Name } \\
\text { Spizella arborea }\end{array}$} & \multicolumn{4}{|c|}{ Bait Type } \\
\hline & & \multicolumn{4}{|c|}{$\begin{array}{c}\text { Mean Number Per Hour } \\
\text { (Percent Frequency of Occurrence) }\end{array}$} \\
\hline & & $2.23(14)$ & $1.61(9)$ & $0.70(7)$ & $0.62(10)$ \\
\hline Vesper sparrow & $\begin{array}{l}\text { Pooecetes } \\
\text { gramineus }\end{array}$ & $0.01(1)$ & $0.01(<1)$ & $0.01(<1)$ & $0.00(0)$ \\
\hline $\begin{array}{l}\text { Savannah } \\
\text { sparrow }\end{array}$ & $\begin{array}{l}\text { Passerculus } \\
\text { sandwichensis }\end{array}$ & $0.00(0)$ & $0.24(7)$ & $0.26(7)$ & $0.01(<1)$ \\
\hline Song sparrow & $\begin{array}{l}\text { Melospiza } \\
\text { melodia }\end{array}$ & $0.00(0)$ & $0.25(3)$ & $0.33(2)$ & $0.03(2)$ \\
\hline Dark-eyed junco & Junco hyemalis & $0.07(2)$ & $0.13(5)$ & $0.05(3)$ & $0.03(2)$ \\
\hline Lapland longspur & $\begin{array}{l}\text { Calcarius } \\
\text { lapponicus }\end{array}$ & $0.05(2)$ & $0.07(<1)$ & $0.01(1)$ & $0.01(<1)$ \\
\hline $\begin{array}{l}\text { Western } \\
\text { meadowlark }\end{array}$ & Sturnella neglecta & $0.12(8)$ & $0.15(9)$ & $0.09(5)$ & $1.70(6)$ \\
\hline Unknown species & & $0.00(0)$ & $0.01(<1)$ & $0.20(3)$ & $0.00(0)$ \\
\hline Mean & & $2.80(29)$ & $2.98(38)$ & $1.85(34)$ & $1.85(26)$ \\
\hline
\end{tabular}

${ }^{a} n=86$ observation hours

${ }^{h} n=152$ observation hours 
Table III. Nontarget birds observed in cornfields in east-central South Dakota from 1995 through 1998.

\begin{tabular}{c} 
Year \\
\hline \\
Common Name \\
$1995^{a} \quad 1996^{b} \quad 1997^{c} \quad 1997^{d} \quad 1998^{e}$ Mean Rank \\
\hline
\end{tabular}

\begin{tabular}{llllllll}
\hline $\begin{array}{l}\text { American tree } \\
\text { sparrow }\end{array}$ & 1 & 28 & 5 & 36 & 10 & 16 & 1 \\
Western & 3 & 23 & 9 & 13 & 17 & 13 & 2 \\
meadowlark & & & & & & & \\
Canada goose & 11 & 22 & 12 & 1 & 0 & 9 & 3 \\
Ring-necked & 35 & 7 & 3 & 0 & 2 & 9 & 3 \\
pheasant & & & & & & & \\
American robin & 10 & 1 & 12 & 6 & 6 & 7 & 4 \\
Killdeer & 4 & 4 & 8 & 8 & 12 & 7 & 4 \\
American coot & 0 & 0 & 35 & 0 & 0 & 7 & 4 \\
Dark-eyed junco & 5 & 3 & 0 & 8 & 6 & 4 & 5 \\
Song sparrow & 0 & 9 & 3 & 0 & 7 & 4 & 5 \\
Unknown species & 12 & 1 & 1 & 1 & 3 & 4 & 5 \\
Mourning dove & 1 & 0 & 5 & 4 & 5 & 3 & 6 \\
Downy woodpecker & 6 & 0 & 1 & 4 & 2 & 3 & 6 \\
Horned lark & 0 & 0 & 0 & 7 & 6 & 3 & 6 \\
Savannah sparrow & 0 & 0 & 0 & 0 & 15 & 3 & 6 \\
Northern flicker & 7 & 1 & 0 & 1 & 3 & 2 & 7 \\
Water pipit & 0 & 0 & 0 & 0 & 2 & 2 & 7 \\
Mallard & 5 & 2 & 3 & 0 & 0 & 2 & 7 \\
Lapland longspur & 0 & 0 & 0 & 6 & 0 & 1 & 8 \\
Wood duck & 0 & 0 & 0 & 2 & 1 & $<1$ & 9 \\
Green-winged teal & 1 & 0 & 0 & 0 & 0 & $<1$ & 9
\end{tabular}

Table III. Continued

\begin{tabular}{llllllll}
\hline \multicolumn{7}{c}{ Year } \\
Common Name & $\begin{array}{c}1995^{a} \\
\text { (Percent Frequency of Occurrence) }\end{array}$ & $1996^{b}$ & $1997^{c}$ & $1997^{d}$ & $1998^{c}$ & Mean & Rank \\
\hline Northern shoveler & 0 & 0 & 0 & 1 & 0 & $<1$ & 9 \\
Common snipe & 0 & 0 & 0 & 0 & 3 & $<1$ & 9 \\
Vesper sparrow & 0 & 0 & 1 & 2 & 1 & $<1$ & 9 \\
Number of & 12 & 10 & 12 & 16 & 16 & & \\
Identified Species & & & & & & & \\
Total Individuals & 177 & 111 & 147 & 101 & 150 & & \\
\hline
\end{tabular}

${ }^{a} n=72$ observation hours, 4 fields with 2-0.8 ha plots in each field; Kenyon 1996 ${ }^{h} n=58$ observation hours, 3 fields with 2-0.8 ha plots in each field; Knutsen 1998 $c_{n}=77$ observation hours, 4 fields with 2-0.8 ha plots in each field; Knutsen 1998 $u_{n}=86$ observation hours, 3 fields with 2-0.8 ha plots in each field; This study $e^{e}=66$ observation hours, 4 fields with 2-0.8 ha plots in each field; This study 
family, may be susceptible to DRC-1339 because they feed in open fields and eat rice grains (20).

The number of ring-necked pheasants, mourning doves, and waterfowl recorded in the plots were too small for valid statistical analyses. Ring-necked pheasants and waterfowl are both wary, particularly during the early spring, and thus probably avoided our study plots because of their proximity to traveled roads. Mourning doves are not susceptible to spring baiting with DRC-1339 because they do not arrive in east-central South Dakota in significant numbers until late April, after the baiting has been completed.

\section{Conclusions}

The purpose of our study was to evaluate bird use of three bait offerings placed within harvested cornfields. Of the 10 most commonly observed nontarget birds, the western meadowlark was probably the most susceptible to poisoning due to its abundance, feeding habits, size, and possible chemical susceptibility to DRC-1339. Even so, this bird is very common (21), and DRC-1339-treated brown rice is unlikely to significantly affect the population. The ring-necked pheasant may also be vulnerable to acute and chronic DRC-1339 poisoning (22). The other eight species of nontargets are not susceptible to a spring-baiting program because of their size, food habits, behavior, or high tolerance to DRC-1339.

\section{Future Research}

We recommend two studies to further clarify the hazards of DRC-1339 to springmigrating nontarget birds: 1 . A food habits study of bird species that frequent ricebaited plots to determine which species eat rice and how much they eat. 2 .

Determine the $\mathrm{LD}_{50}$ values for rice-eating species observed in the baited plots.

\section{Acknowledgments}

We thank B. Bonesteel and T. Slowik for their help with the field observations. The Animal Nutrition Laboratory of the Department of Animal and Range Sciences, North Dakota State University, conducted the chemical analyses of the food. P. Pochop and R. Sayre provided helpful suggestions on an earlier draft. This study was conducted under the auspices of National Wildlife Research Center study protocol QA-437. Procedures involving use and care of birds were reviewed and approved by the Animal Use and Care Committee, National Wildlife Research Center.

\section{References}

1. Cummings, J. L., J. L. Guarino, and C. E. Knittle. Chronology of blackbird damage to sunflowers. Wildl. Soc. Bull. 1989. 17:50-52.

2. Hothem, R. L., R. W. DeHaven, and S. D. Fairazl. Bird damage to sunflower in North Dakota, South Dakota and Minnesota, 1979-1981. U.S. Fish and Wildlife Tech. Rep. 15. 1988. 11 pp.

3. Linz, G. M., and J. J. Hanzel. Birds and sunflower. In A. Schneider, ed. Sunflower Science and Technology. Am. Soc. of Agron., Madison, Wis. 1997. Pages 381-394.

4. Linz, G. M., and H. J. Homan. Tracing the history of blackbird research through an industry's looking glass: The sunflower magazine. Vertebr. Pest Conf. 1998. $18: 35-42$.

5. DeCino, T. J., D. J. Cunningham, and E. W. Schafer. Toxicity of DRC-1339 to starlings. J. Wildl. Manage. 1966. 30:249-253.

6. Barras, A. M.S. thesis, North Dakota State University, Fargo, North Dakota, 1996.

7. Knittle, C. E., G. M. Linz, J. L. Cummings, J. E. Davis, Jr., B. E. Johns, and J. F. Besser. Spring migration patterns of male red-winged blackbirds (Agelaius phoeniceus) from two migratory roosts in South Dakota and Minnesota. Am. Midl. Nat. 1996. 136: 134-142.

8. Gober, P. Section 7 Biological Opinion. September 29, 1998. U.S. Department of Interior, Fish and Wildlife Service, Pierre, South Dakota. Letter - 9 pp.

9. Knutsen, G. A. M.S. thesis, North Dakota State University, Fargo, North Dakota, 1998.

10. South Dakota Agricultural Statistics Service. South Dakota Agricultural Statistics. S.D. Dep. Agric., Sioux Falls, SD, 1999.

11. Linz, G. M, L. A. Mendoza, D. L. Bergman, and W. J. Bleier. Preference of three blackbird species for sunflower meats, cracked corn, and brown rice. Crop Protection. 1995. 14:375-378.

12. U.S. Department of Agriculture. Animal Damage Control Program Final Environmental Impact Statement. Appendix P. Risk assessment of wildlife damage control methods used by the USDA Animal Damage Control Program. Washington, D.C. 1994. pp. 194-210.

13. Mah, J. Ph.D. dissertation, North Dakota State University, Fargo, North Dakota, 1988.

13. Conover, W. J. Practical Nonparametric Statistics, $2^{\text {nd }}$ ed. John Wiley \& Sons, New York. 1980.

14. Mason, J. R., R. A. Dolbeer, A. H. Arzt, R. F. Reidinger and P.P. Woronecki. Taste preferences of male red-winged blackbirds among dried samples of ten corn hybrids. J. Wildl. Manage. 1984. 48:611-616.

15. Mason, J. R., G. Nuechterlein, G. Linz, R. A. Dolbeer, and D. L. Otis. Oil concentration differences among sunflower achenes and feeding preference of red-winged blackbirds. Crop Protection. 1991. 10:299-304. 
16. Kenyon, M. J. M.S. thesis. North Dakota State University, Fargo, North Dakota, 1996.

17. DeGraaf, R. M., N. G. Tilghman, and S. H. Anderson. Foraging guilds of North American birds. Environ. Manage. 1985. 9:493-536.

18. Hirst, S. M., and C. A. Easthope. Use of agricultural lands by waterfowl in southwestern British Columbia. J. Wildl. Manage. 1981. 45:454-462.

19. Schafer, Jr., E. W., R. B. Brunton, D. J. Cunningham, and N. Lockyer. The chronic toxicity of 3-chloro-4-methyl benzamine HCL to birds. Arch. Environ. Contam. Toxicol. 1977. 6:241-248.

20. Flickinger, E. L., and K. A. King. Some effects of aldrin-treated rice on Gulf Coast wildlife. J. Wildl. Manage. 1972. 36:706-727.

21. Igl, L. D., and D. H. Johnson. Changes in breeding bird populations in North Dakota: 1967 to 1992-93. Auk. 1997. 114:74-92.

22. Avery, M. L., M. J. Kenyon, G. M. Linz, D. L. Bergman, D. G. Decker, and J. S. Humphrey. Potential risk to ring-necked pheasants from application of toxic bait for blackbird control in South Dakota. J. Wildl. Manage. 1998. 62:388-394. 